\title{
DIMENSI SPIRITUAL DALAM KEPEMIMPINAN
}

\author{
Arcadius Benawa \\ Character Building Development Center (CBDC), BINUS University \\ Jln. Kemanggisan Ilir III No. 45, Kemanggisan - Palmerah, Jakarta 11480 \\ aridarsana@yahoo.com
}

\begin{abstract}
This article aims to show that the spiritual aspect must be noted in the leadership because every leader is always marked with oath of office in carrying out her/his position. So, how leaders are accountable, it is not only on the horizontal level but also at the vertical level. Research was done with phenomenological and literature studies about the practice of leadership faced with a number of theories about leadership and then to be synthesized the more authentic leadership than just imaging or false branding leadership. This article was based on the assumption that leadership (including in the political sphere) was merely a sociological problem that kicked out spiritual aspects, while in the historical development of leadership, it had never been excluded from the spiritual dimension, whether in the form of manipulative (just because fed people understand that leadership came from the "sky"/gods). So then, a king acted tyrannical and led to the birth of authentic leadership as popularized as servant leadership. This article concluded that authentic leadership will give more benefit to develop the life system as well as the purpose of leadership itself rather than a merely apparent leadership which actually hurts the members (people) because of the failure to meet the expectations of the members (people).
\end{abstract}

Keywords: authentic leadership, spiritual leadership, apparent leadership

\begin{abstract}
ABSTRAK
Tulisan bertujuan untuk menunjukkan bahwa aspek spiritual patut diperhatikan di dalam kepemimpinan karena setiap pemimpin dalam mengemban jabatannya selalu ditandai dengan sumpah jabatan. Dengan demikian bagaimana pemimpin itu mempertanggungjawabkan kepemimpinannya tidak hanya pada tataran horizontal, tetapi juga pada tataran vertikal. Penelitian menggunakan kajian fenomenologis dan pustaka seputar praktik kepemimpinan dihadapkan dengan sejumlah teori tentang kepemimpian disintesiskan kepemimpinan yang lebih otentik daripada sekadar pencitraan. Tulisan bertitik tolak dari asumsi bahwa seolah kepemimpian (termasuk di ranah politik) adalah persoalan sosiologis semata yang menendang aspek spiritual, sementara dalam perkembangan sejarah ternyata kepemimpinan senantiasa tidak pernah luput dari dimensi spiritual, entah dalam bentuk yang bersifat manipulatif (bahwa kepemimpian berasal dari langit/dewa-dewi). Lantas, raja bertindak tirani maupun yang justru mendorong lahirnya kepemimpinan otentik sebagaimana populer dalam istilah servant leadership. Kesimpulannya, kepemimpinan otentik lebih mendatangkan manfaat bagi terbangunnya tatanan kehidupan yang lebih baik sebagai tujuan dari kepemimpinan itu sendiri daripada kepemimpinan semu yang hanya bersifat tebar pesona dan justru menyakiti anggota (rakyat) karena tidak terpenuhinya harapan dari anggota (rakyat).
\end{abstract}

Kata kunci: kepemimpinan otentik, kepemimpinan spiritual, kepemimpinan semu 


\section{PENDAHULUAN}

Wujud yang paling akrab dalam pengamatan yang tiada reda semaraknya adalah merebaknya praktik korupsi, kolusi, dan nepotisme. Sementara, dasar negara Indonesia jelas-jelas mencantumkan sila pertama dalam Pancasila "Ketuhanan Yang Maha Esa". Apalagi, di dalam setiap jabatan pemimpin di negeri ini selalu ditandai dengan ritual "sumpah jabatan". Realitas memprihatinkan seperti itu cukup membuktikan bahwa tidak ada perhatian pada aspek spiritual dalam praktik kepemimpinan di negeri ini. Sementara seorang pemimpin tentu dituntut adanya trust (kepercayaan) di dalam dirinya. Bagaimana pemimpin akan mendapatkan trust dari anggotanya jika ia tidak setia pada kebenaran yang diwujudkan dalam praktik-praktik terselubung ataupun terang-terangan yang melukai hati konstituen. Dalam bahasa populer, konstituen butuh bukti bukan janji. Misalnya terhadap tekad pemimpin untuk memberantas KKN (Korupsi, Kolusi, dan Nepotisme), dalam praktik justru pemimpin ditengarai menjadi pemicu pembenaran praktik KKN. Hal ini tentu sangat melukai hati konstituen yang berujung pada merosotnya tingkat elektabilitas pemimpin dalam pemilihan calon pemimpin di periode berikutnya.

Melalui momentum Pemilu 2014, sejumlah persoalan mengemuka. Persoalan tersebut antara lain: (1) seperti apakah wajah kepemimpinan di Indonesia pasca Pemilu 2014? Bagaimanakah pemetaannya secara makro maupun mikro? Persoalan-persoalan krusial seperti apa yang sudah, sedang dan masih mungkin akan muncul selama fase Pemilu 2014 dan setelahnya? (2) Adakah sumbangan yang berarti dari dunia pendidikan untuk memperlancar, atau malah mungkin juga mendistorsi proses pematangan, bahkan mungkin juga membusukkan demokrasi dalam Pemilihan Umum? (3) Bagaimana membingkai dan menganalisis dramaturgi politik pasca-Pemilu 2014 dalam bingkai politik pencitraan? Adakah sesuatu yang bernilai, pantas, dan berharga yang dapat dipelajari dari situ sebagai modal dan bekal menjadi warga negara Republik Indonesia yang lebih santun, beradab, dan demokratis? Terpicu persoalan-persoalan tersebut, tulisan ini hendak menyorot aspek spiritual dalam kepemimpinan, yang dalam realitasnya kerap dilalaikan pada praktiknya. Walaupun dalam ritual pelantikan pemimpin, aspek spiritual itu ditampakkan dengan jelas dalam acara "sumpah jabatan”.

\section{METODE}

Untuk mencapai tujuan penelitian tersebut penulis meneliti literatur akademis tentang spiritualitas dan kepemimpinan. Gea, A. et. al. (2004: 308) dalam bukunya "Relasi dengan Tuhan" mengungkapkan bahwa salah satu wujud dari kesetiaan pada kebenaran adalah setia janji. Namun bagaimana pemimpin bisa diharapkan setia pada janji jika pada level sumpah saja ia telah berani melanggar. Hal ini sudah mengindikasikan secara kuat tidak adanya kesetiaan pemimpin pada kebenaran, bagaimana pemimpin yang tidak setia pada kebenaran akan membangun trust di antara konstituennya. Paling jauh pemimpin yang tidak setia pada kebenaran akan membangun dengan model pencitraan, namun jelas bahwa pencitraan yang tidak otentik itu tidak bertahan lama, minimal masih harus diuji otentisitas kebaikannya kalau citra baik yang mau ia bangun di antara konstituennya.

Menurut U.S. Army Handbook, seperti dikutip Susanto (2010:16) terdapat tiga gaya utama kepemimpinan, yakni otoriter atau otokratis, partisipasi atau demokrat, dan delegasi atau pemerintahan bebas. Gaya kepemimpinan otoriter (otokratis) diterapkan manakala pemimpin meminta anak buah untuk melakukan apa yang diinginkan. Sifat dari gaya kepemimpinan ini tidak mengenal kompromi. Yang penting, pengikut melakukan kewajiban, sebab dalam kewajiban tersebut sudah termaktub kebijaksanaan dan kebaikan. Gaya ini diterapkan dalam kondisi ketika seorang pemimpin memiliki semua informasi untuk memecahkan masalah, mengejar waktu, dan karyawan juga termotivasi. 
Beberapa pemimpin menerapkan gaya otokratis sebagai "kendaraan” untuk berteriak, menggunakan bahasa yang merendahkan, dan memimpin dengan ancaman dan menyalahgunakan kekuasaan. Gaya kepemimpinan ini cenderung kasar. Pemimpin memerintah orang-orang sekitar dengan tangan besi. Tidak ada kesempatan untuk mengulang apa yang telah diperintahkan. Sekali pemimpin berkata, anak buah wajib melaksanakannya tanpa banyak bertanya. Gaya otoriter biasanya digunakan hanya pada saat tertentu. Umumnya, pemimpin yang mempraktikkan gaya ini adalah orang yang otoriter, omnipotentia. Dalam sejarah, Kaisar Nero dikenal sebagai pemimpin otoriter. Nero dikenal dengan semboyannya yang sangat terkenal, "Orderint, dum metuant". Artinya, biar mereka (rakyat) benci, asal takut.

Gaya kepemimpinan kedua adalah participation (demokrat). Dengan gaya kepemimpinan ini tidak segera mendapat hasil dan mencapai tujuan, tetapi lebih bersahabat dan egaliter. Bahasa yang digunakan bukan perintah namun lebih sebagai ajakan, misalnya: "Mari bersama-sama, bahu membahu memecahkan dan mencapai tujuan bersama ...." Gaya kepemimpinan partisipatif melibatkan anggota, termasuk satu atau lebih karyawan dalam proses pengambilan keputusan. Secara tim, mereka menentukan apa yang harus dilakukan dan bagaimana melakukannya namun pemimpin tetap orang yang paling bertanggung jawab. Jika pemimpin menerapkan gaya ini, bukan berarti suatu organisasi atau lembaga lemah. Sebaliknya, justru menunjukkan kekuatan bahwa seorang pemimpin dihormati anak buahnya. Gaya kepemimpinan ini lazim diterapkan ketika seorang pemimpin memiliki informasi yang cukup mengenai kekuatan dan kelemahan anak buah, sehingga dapat membagi tugas dan tanggung jawab sesuai dengan keterampilannya masing-masing. Untuk mencapai tujuan organisasi, atau lembaga, seorang pemimpin tidak bekerja sendiri. Ia bekerja bersama orang lain, bekerja dalam tim. Diandaikan gaya ini diterapkan ketika warganya memiliki pengetahuan dan terampil. Semua warga punya potensi. Tinggal digali, dikembangkan, diarahkan untuk mencapai tujuan. Pemimpin bertugas mengarahkan dan memaksimalkan kemampuan anak buah. Gaya kepemimpinan partisipatif ini cocok bagi warga yang sudah terdidik dan paham mengenai hak dan kewajibannya. Baik pemimpin maupun warga saling menguntungkan. Setiap warga menjadi bagian utuh organisasi, sehingga memungkinkan pemimpin untuk membuat keputusan yang lebih baik.

Gaya kepemimpinan ketiga adalah pemerintahan bebas atau delegasi. Dalam gaya ini, pemimpin memungkinkan anak buah untuk membuat keputusan. Akan tetapi, pemimpin tetap bertanggung jawab atas keputusan yang dibuat. Gaya ini akan berhasil manakala anak buah mampu menganalisis situasi dan menentukan apa yang perlu dilakukan dan bagaimana melakukannya. Seorang pemimpin tidak dapat melakukan semuanya seorang diri. Ia harus pandai membaca situasi, mana tugas yang harus didelegasikan dan mana yang tidak. Yang didelegasikan hanyalah tugas tertentu saja. Pendelegasian tugas, bukan berarti tidak ada yang bertanggung jawab. Jika terjadi kesalahan, tidak bisa menimpakan kegagalan, lalu menyalahkan orang lain. Sadarilah bahwa gaya ini adalah pilihan, dengan kelebihan dan kekurangannya.

Model kepemimpinan ala Pilatus yang mengaburkan kebenaran yang terang benderang pastilah memuakkan. Dari Injil Yohanes 18:36, diketahui Pilatus mempertanyakan "kebenaran” yang dicanangkan Yesus karena ia mau mengaburkan kebenaran dengan tindakan simbolis "mencuci tangan” terhadap kasus yang menyeret Yesus pada tuntutan hukuman salib, sebuah hukuman paling nista waktu itu bagi khalayak Yahudi. Pasalnya, hukuman berat yang "layak" bagi orang Yahudi adalah "rajam". Namun sedemikian nistanya sosok Yesus yang dituduh telah menghujat Allah sehingga orang Yahudi merasa najis untuk menjatuhkan hukuman mati bagi Yesus. Oleh karena itu, dipakailah tangan orang Romawi melalui hukuman salib, dan untuk itu tuduhan pun dibuat relevan dengan bahasa penguasa waktu itu, yakni subversif. Seperti tertulis dalam Injil Lukas 23: 38, Injil Yohanes 19: 19, Yesus dituduh mengaku sebagai Raja orang Israel, sehingga di salib-Nya dituliskan tuduhan terhadap-Nya, yakni INRI (Iesus Nazarenus Rex Ieudeorum = Yesus orang Nazareth, Raja orang Yahudi). 
Model kepemimpian Pilatus jelas mengisyaratkan kepemimpinan yang berorientasi pada status quo dan melalaikan keutamaan-keutamaan yang mestinya melekat pada sosok seorang pemimpin, seperti setia pada kebenaran. Ia yang jelas-jelas menemukan tidak adanya kesalahan pada Yesus itu menyerahkan proses penyaliban Yesus pada bangsa Yahudi dengan ungkapannya yang terkenal: “Aku tidak bertanggung jawab atas darah orang ini!” Pemimpin yang "membiarkan” yang disimbolkan dengan adegan cuci tangan tersebut menjadi biang anarkisme di tengah masyarakat. Rupanya hal itulah pula dalam konteks Indonesia yang kerap dirasakan oleh warganya. Beberapa fenomena bisa disebutkan. Sebagai contoh, antara lain: pembiaran terhadap perilaku anarkis ormas tertentu terhadap kelompok-kelompok lain, baik berupa perusakan fasilitas fisik bangunan maupun penganiayaan fisik terhadap kelompok teraniaya. Belum terselesaikannya kasus-kasus korupsi yang ditengarai akan menyeret sejumlah elite pemimpin negeri ini juga mengisyaratkan adanya pembiaran kasusnya tergantung di atas awan dan ditutup-tutupi dengan model pengalihan perhatian.

Sementara pemimpin berdimensi spiritual. Misalnya kepemimpinan ala Yesus yang tidak disukai pemimpin masyarakat karena risikonya jelas, yakni salib (baca: kebinasaan). Salib tak mungkin terhindarkan pada pemimpin yang menyadari bahwa kepemimpinannya tidak semata-mata dipertanggungjawabkan pada level sosial kemasyarakatan (horizontal) melainkan juga pada level ilahi (vertikal). Alasannya kiranya jelas, yakni pada level horizontal seorang pemimpin dengan keahliannya menutup-nutupi kesalahan, ia bisa memainkan citra dirinya sebagai seolah-olah pemimpin yang baik. Syaratnya jelas, sejauh tidak bisa dibuktikan secara yuridis tuduhan terhadap kesalahannya akan menjadi tuntutan balik sebagai mendiskreditkan pemimpin atau bahkan dituduh subversif. Sementara jika pemimpin menyadari dimensi spiritual dalam kepemimpinannya, ia harus mempertanggungjawabkan kepemimpinannya pada Yang Ilahi, yang dipercayai sebagai yang mahatahu, pun terhadap kesalahan atau kejahatan yang tampak nyata maupun yang ditutup-tutupi, sehingga kabur kebenarannya di mata manusia, tetapi tidak demikian di mata Tuhan. Sementara secara formal pemimpin melakukan sumpah jabatan; artinya, ia menyadari bahwa jabatan kepemimpinannya ia terima dari Atas dan harus dipertanggungjawabkan kepada Sang Pemberi Amanah juga.

Merebaknya pemimpin yang meniadakan dimensi spiritual itu mendorong pakar kepemimpian, Greenleaf dan Frick (2008) menggaungkan kembali pentingnya dimensi spiritual. Greenleaf yang adalah Vice President American Telephone and Telegraph Company (AT\&T) itu melakukan penelitian dan pengamatan terhadap kepemimpinan pelayan untuk membangun kondisi masyarakat yang lebih baik dan lebih peduli. Greenleaf berpandangan bahwa yang dilakukan pertama kali oleh seorang pemimpin besar adalah melayani orang lain. Kepemimpinan yang sejati (authentic leadership) timbul dari mereka yang motivasi utamanya adalah keinginan menolong orang lain.

Konsekuensinya, model-model kepemimpinan yang bersifat otokratis dan hierarkis menjadi usang. Model kepemimpinan yang melayani adalah kepemimpinan yang secara simultan meningkatkan pertumbuhan anggota dan meningkatkan kompetensi potensial anggotanya dengan sepenuh hati dan penuh perhatian. Greenleaf membicarakan perlunya model kepemimpinan yang menempatkan pelayanan kepada orang lain, termasuk karyawan, pelanggan, dan masyarakat sebagai prioritas nomor satu. Dengan demikian kepemimpinan pelayan menekankan peningkatan pelayanan kepada orang lain. Greenleaf menyatakan bahwa pemimpin pelayan adalah orang yang mula-mula menjadi pelayan. Kemudian pilihan sadarnya membawa orang untuk memimpin, justru karena terdorong oleh kepeduliannya terhadap kebutuhan orang lain, yang menempatkan kebutuhan orang lain sebagai prioritas tertinggi.

Dengan alur seperti itu, tampak betapa jauh berbeda dengan orang yang belum-belum sudah ingin menjadi pemimpin lebih dulu. Tendensi seperti itu mungkin karena terdorong oleh hasrat untuk berkuasa atau mungkin juga karena dorongan untuk memperoleh hak milik duniawi. Memimpin dulu dan melayani dulu adalah tipe yang berbeda. Perbedaannya tampak dalam kepedulian yang diambil oleh pelayan lebih dulu untuk memastikan bahwa prioritas kebutuhan orang lain adalah mendapatkan pelayanan. Ujian yang terbaik dan sulit untuk dilaksanakan adalah apakah mereka yang dilayani itu 
tumbuh sebagai pribadi yang lebih sehat (baik), bijaksana, bebas, mandiri, dan memungkinkan diri mereka menjadi pelayan juga. Dan apakah berpengaruh juga terhadap tanggung jawabnya pada lingkungan social.

Sementara Depree (2003) mengatakan bahwa kepemimpinan pelayan adalah respek terhadap orang lain. Artinya, apakah seorang pemimpin itu pertama-tama mengerti bahwa setiap manusia memiliki kemampuan, bakat, dan kekuatan yang berbeda. Perbedaan ini menuntut pemimpin untuk dapat menumbuhkan rasa saling percaya. Sebagai individu dan bagian suatu kelompok tentu berkeinginan untuk dapat mewujudkan potensinya semaksimal mungkin. Seni dari kepemimpinan bersandar pada kemampuan memfasilitasi, memberi kesempatan dan memaksimalkan setiap bakat yang berbeda dari setiap individu. Kepemimpinan menuntut kedewasaan yang khusus. Kedewasaan tersebut diekspresikan dengan menghargai diri sendiri, perasaan memiliki, perasaan yang penuh pengharapan, perasaan tanggung jawab, persamaan tanggung jawab dan perasaan yang meyakini bahwa pada dasarnya manusia itu sama.

\section{HASIL DAN PEMBAHASAN}

Penelitian ini menunjukkan bahwa keterlibatan unsur iman ataupun spiritual dalam konsep kepemimpinan menjadi jelas dalam model kepemimpinan pelayan. Artinya, makin pemimpin itu menunjukkan keberimanannya atau spiritualitasnya, makin jelas pula konsep kepemimpinannya yang tersaji dalam model kepemimpinannya yang melayani, bukan menguasai.

Hal ini sejalan dengan temuan yang dikemukakan oleh Sahertian (2012) bahwa ada hubungan antara kepemimpinan spiritual dan teori-teori kepemimpinan berbasis nilai lain. Meskipun kepemimpinan spiritual masih lebih merupakan wawasan teoretis, hal itu tetap merupakan tujuan penting, terutama berkaitan dengan teori-teori kepemimpinan lainnya. Demikian yang ditemukan Freeman (2011); ia membuktikan bahwa keyakinan spiritual (misalnya, harapan dan iman kepada Allah) sebagai faktor penyebab dalam pembentukan nilai-nilai dan perilaku pemimpin yang melayani.

Kepemimpinan pelayan memandang masalah apa saja di dunia sebagai masalah di sini, di dalam diri sendiri, bukan di luar sana. Maka jika pemimpin ingin mengobati suatu cacat anggota atau masyarakat, pemimpin pelayan harus memulai proses perubahan/penyembuhannya dari sini, dalam diri pelayan, bukan di luar sana. Pada intinya kepemimpinan pelayan adalah pendekatan jangka panjang yang memberikan perubahan kepada kehidupan dan kerja demi menciptakan perubahan positif di seluruh kehidupan masyarakat.

Banyak sekali individu dan perusahaan-perusahaan besar dunia telah menjadikan kepemimpinan pelayan sebagai falsafah hidup. Banyak tokoh dunia yang menerapkan kepemimpinan pelayan ini, dan mereka dianggap menjadi pemimpin yang besar, contoh: Nabi Muhammad, Yesus, Kong $\mathrm{Hu} \mathrm{Cu}$, Gandhi, Abraham Lincoln, Ki Hajar Dewantara, dan masih banyak pemimpin besar lainnya. Para penulis, pemikir, dan pemimpin yang terkemuka pun memberikan respons yang positif bagi kemunculan kepemimpinan pelayan.

DePree (2003) dan Leadership Jazz mengatakan bahwa fungsi kepemimpinan pelayan perlu dirasakan, dipahami, diyakini, dan dipraktikkan. Senge (1994), dalam mengatakan bahwa ide Greenleaf tentang kepemimpinan pelayan adalah suatu pernyataan yang unik dan berguna tentang kepemimpinan yang pernah dia temukan. Sementara itu, mantan Presiden RI yang ke-4, K.H. Abdurrahman Wahid (Gus Dur) pernah mengatakan bahwa semua unsur pemerintahan di bawah kepimpinannya harus menjadi tulang punggung pelayanan bagi masyarakat. Gus Dur pada saat itu sudah menyadari bahwa Bangsa Indonesia telah kehilangan perekat sosial. Isu sentral masyarakat Indonesia saat ini adalah membangun kembali kepercayaan, kepercayaan kepada pimpinan, entah 
dalam perusahaan, sekolah, lembaga keagamaan, pemerintahan, serta bagaimana membangun kepercayaan antara satu dengan yang lainnya.

Saat ini ketiadaan rasa saling percaya telah menumbuhkan kebencian dan kemarahan pada sebagian besar masyarakat Indonesia. Maka melalui momentum Pemilu 2014, perlu diingat kembali wasiat Gus Dur bahwa yang memegang kekuasaan tertinggi adalah rakyat, oleh karena itu rakyat yang harus dilayani. Gus Dur seolah-olah mau menekankan bahwa jika ingin membangun masyarakat yang lebih baik, masyarakat yang lebih adil dan lebih penuh kasih sayang, masyarakat yang penuh kreativitas, maka cara yang paling terbuka adalah meningkatkan kemampuan untuk melayani maupun unjuk kerja sebagai pelayan.

Dalam persfektif Jawa kepemimpinan pelayan telah dikenal sejak dulu. Konsep kepemimpinan ini telah lama dikenal dalam tradisi luhur masyarakat kita, seperti yang tertuang dalam kumpulan seloka "Asta Brata" yang berisikan ajaran-ajaran Hindu tentang bagaimana seharusnya menjadi pemimpin yang baik. Menurut Arifin (1968), Asta Brata adalah contoh kepemimpinan yang terdapat dalam Ramayana. Asta Brata adalah delapan tipe kepemimpinan yang merupakan 8 (delapan) sifat Kemahakuasaan Tuhan. Ajaran ini diberikan Sri Rama kepada Wibhisana sebagai Raja Alengka Pura saat menggantikan kakaknya Rahwana. Kedelapan ajaran Asta Brata adalah sebagai berikut.

Indra Brata, artinya pemimpin hendaknya mengikuti sifat-sifat Dewa Indra sebagai dewa pemberi hujan, yang memberi kesejahtraan kepada rakyat. Yama Brata, artinya pemimpin hendaknya mengikuti sifat-sifat Dewa Yama, yaitu menciptakan hukum, menegakkan hukum, dan memberikan hukuman secara adil kepada setiap orang yang bersalah. Surya Brata, hendaknya pemimpin memberikan penerangan secara adil dan merata kepada seluruh rakyat yang dipimpinnya serta selalu berbuat berhati-hati seperti matahari yang sangat berhati-hati dalam menyerap air. Candra Brata, pemimpin hendaknya selalu dapat memperlihatkan wajah yang tenang dan berseri-seri, sehingga masyarakat yang dipimpinnya merasa yakin akan kebesaran jiwa dari pemimpinnya. Bayu Brata, pemimpin hendaknya selalu dapat mengetahui dan menyelidiki keadaan serta kehendak yang sebenarnya terutama keadaan masyarakat yang hidupnya paling menderita. Kuwera Brata, pemimpin hendaknya harus bijaksana mempergunakan dana atau uang serta selalu ada hasrat untuk mensejahtrakan masyarakat dan tidak menjadi pemboros yang akirnya dapat merugikan negara dan masyarakat. Baruna Brata, pemimpin hendaknya dapat memberantas segala bentuk penyakit yang berkembang di masyarakat, seperti pengangguran, kenakalan remaja, pencurian dan pengacau keamanan negara. Agni Brata, pemimpin harus memiliki sifat-sifat selalu dapat memotivasi tumbuhnya sifat ksatria dan semangat yang berkobar dalam menundukkan musuh-musuhnya.

Dalam perspektif Buddha, menurut Berndt (2006), terdapat ciri-ciri tertentu yang harus dimiliki oleh seorang pemimpin Buddhis, yakni dengan mengembangkan Jalan Mulia Berunsur Delapan yang meliputi tiga kelompok yaitu: kelompok Panna (kebijaksanaan), Sila (moralitas), Samadhi (konsentrasi). Kelompok panna (kebijaksanaan) terdiri dari: (1) pemahaman benar, yaitu pengetahuan akan sifat sejati kehidupan; pemahaman atas Empat Kesunyataan Mulia; (2) pikiran benar, yaitu pikiran yang bebas dari sensualitas, niat buruk, dan agresi. Kelompok Sila (moralitas) terdiri dari: (3) ucapan benar, yaitu pantang dari kebohongan, ucapan kasar, dan perkataan yang tak berguna; (4) tindakan benar, yaitu pantang dari pembunuhan, pencurian, dan perbuatan seksual yang menyimpang; (5) penghidupan benar, yaitu menghindari segala bentuk penghidupan yang melibatkan pengrusakan dan eksploitasi makhluk lain. Kelompok Samadhi (konsentrasi) terdiri dari; (6) usaha benar, yaitu melatih pikiran untuk menghindari keadaan mental yang tidak bermanfaat dan mengembangkan keadaan mental yang bermanfaat; (7) perhatian benar, yaitu mengembangkan kekuatan perhatian dan kesadaran terhadap empat dasar perhatian; tubuh, perasaan, pikiran, dan fenomena mental; dan (8) konsentrasi benar, yaitu pengembangan pikiran yang terpusat.

Bagaimanapun seorang pemimpin, tentu mereka mempunyai kriteria-kriteria tersendiri antara lain, ia mempunyai kelebihan-kelebihan, lebih kuat, lebih pandai. Lebih memiliki kualitas pribadi 
yang unggul, serta lebih memiliki kualitas pribadi yang unggul, serta lebih memiliki kesempatan dari pada orang lain. Seorang pemimpin mendapat mandat untuk bekerja memenuhi keperluan orang banyak. Kekuasaan yang dimiliki hanya dalam rangka memenuhi kewajiban sebagai seorang pemimpin. Dalam pandangan Buddhis pemimpin tidaklah beda dengan bawahan. Pandangan mengenai martabat dan derajat dari perlakuan yang sama pada semua manusia, menunjukkan sifat agama Buddha yang demokratis.

Prinsip-prinsip kepemimpinan Jawa, menurut Tugiman (1999), tercermin dalam trilogi kepemimpinan yang dikenalkan oleh Ki Hajar Dewantara, yakni ing ngarsa sung tulada (di depan pemimpin harus menjadi teladan/role model dalam perannya sebagai pengarah/directing), ing madya mangun karsa (di tengah-tengah anggota yang dipimpinnya ia harus membangun semangat-sebagai animator), dan tut wuri handayani (memberi dorongan jika pemimpin berada di belakang-sebagai motivator). Konsep kepemimpinan pelayanan yang menonjolkan pelayanan kepada orang lain, termasuk pada bawahan akan semakin menumbuhkan keterikatan yang kuat antara pimpinan dan bawahan. Tanggung jawab ke bawah (downward accountability) akan menjadikan kepemimpinan itu berakar dan diterima dengan tulus oleh bawahan. Dalam persfektif Jawa pun dikenal istilah sifat tumungkul (tanggung jawab ke bawah) yang harus dimiliki oleh seorang pemimpin. Jadi jelas bahwa kepemimpinan bukanlah suatu popularitas, bukan kekuasaan, bukan keahlian melakukan pertunjukkan, dan bukan kebijaksanaan dalam perencanaan jangka panjang semata. Dalam bentuk yang paling sederhana kepemimpinan adalah menyelesaikan sesuatu bersama orang lain dan membantu orang lain dalam mencapai suatu tujuan bersama.

\section{Sepuluh Ciri Khas Kepemimpinan Pelayan}

Lebih lanjut dari beberapa tulisan Greenleaf, Frick, dan Spears (1996) menyimpulkan bahwa sedikitnya terdapat sepuluh ciri khas kepemimpinan pelayan yang paling dominan. Pertama, mendengarkan (listening receptively to what others have to say). Secara tradisional, pemimpin dihargai karena keahlian komunikasi dan kemampuan mereka dalam pembuatan keputusan. Pemimpin pelayan harus memperkuat keahlian yang penting ini dengan menunjukkan komitmen yang mendalam dalam mendengarkan secara intensif ide-ide atau kata-kata orang lain. Pemimpin pelayan berusaha mengenali dan memahami dengan jelas kehendak kelompok. Mereka berusaha mendengarkan secara tanggap apa yang dikatakan (dan tidak dikatakan). Mendengarkan dan memahami apa yang dikomunikasikan oleh tubuh, jiwa dan pikiran.

Kedua, menerima orang lain dan empati (acceptance of others and having empathy for them). Pemimpin pelayan berusaha keras memahami dan memberikan empati kepada orang lain. Orang perlu diterima dan diakui sebagai suatu individu yang istimewa dan unik. Setiap individu tidak ingin kehadirannya dalam suatu organisasi/perusahaan ditolak oleh orang lain yang berada di sekitar dirinya. Pemimpin pelayan yang paling sukses adalah mereka yang mampu menjadi seorang pendengar yang penuh dengan empati.

Ketiga, kemampuan meramalkan (foresight and intuition). Kemampuan untuk memperhitungkan kondisi yang sudah terjadi atau meramalkan kemungkinan hasil suatu situasi sulit didefinisikan, tetapi mudah dikenali. Orang mengetahui kalau melihatnya. Kemampuan meramalkan adalah cirri khas yang memungkinkan pemimpin pelayan bisa memahami pelajaran dari masa lalu, realita masa sekarang dan kemungkinan konsekuensi sebuah keputusan untuk masa depan. Hal ini menanamkan inti permasalahan sampai jauh ke dalam pikiran intuitif. Jadi kemampuan meramalkan adalah salah satu cirri khas pemimpin pelayan yang dibawa sejak lahir. Semua ciri khas lainnya bisa dikembangkan secara sadar.

Keempat, kesadaran (awareness and perception). Kesadaran akan diri sendiri dan keberadaan orang lain dapat turut memperkuat pemimpin pelayan. Kesadaran juga membantu dalam memahami 
persoalan yang melibatkan etika dan nilai-nilai. Hal ini memungkinkan orang dapat memandang sebagian besar situasi dari posisi yang lebih terintegrasi.

Kelima, membangun kekuatan persuasif (having highly develoved power of persuasion). Ciri khas kepemimpinan pelayan lainnya adalah mengandalkan kemampuan meyakinkan orang lain, bukannya wewenang karena kedudukan, dalam membuat keputusan di dalam organisasi. Pemimpin pelayan berusaha meyakinkan orang lain, bukannya memaksakan kepatuhan. Elemen ini memberikan perbedaan yang paling jelas antara model wewenang tradisional dan model kepemimpinan pelayan. Pemimpin pelayan efektif dalam membangun konsensus dalam kelompok.

Keenam, konseptualisasi (an ability to conceptualize and to communicate concepts). Pemimpin pelayan berusaha memlihara kemampuan mereka untuk "memiliki impian besar". Kemampuan untuk melihat kepada suatu masalah (atau sebuah organisasi) dari persfektif konseptualisasi berarti bahwa orang harus berpikir melampaui realita dari hari ke hari. Manajer tradisional disibukkan oleh kebutuhan untuk mencapai tujuan operasional jangka pendek. Seorang manajer yang ingin menjadi pemimpin pelayan harus mampu mengoptimalkan pemikirannya sampai mencakup pemikiran konseptual yang mempunyai landasan lebih luas (visioner). Pemimpin pelayan harus mengusahakan keseimbangan yang rumit antara konseptualisasi dan fokus sehari-hari.

Ketujuh, kemampuan menyembuhkan (ability to exert a healing influence upon individual and institutions). Belajar menyembuhkan merupakan daya yang kuat untuk perubahan dan integrasi. Salah satu kekuatan besar kepemimpinan pelayan adalah kemampuan untuk menyembuhkan diri sendiri dan orang lain. Banyak orang yang patah semangat dan menderita karena berbagai masalah emosional. Walaupun hal tersebut merupakan sesuatu yang alami dalam kehidupan manusia, seorang pemimpin pelayan harus mampu dan mempunyai kesempatan menggerakkan hati dan memberi semangat kepada orang-orang yang berhubungan dengan mereka.

Kedelapan, kemampuan melayani. Peter Block (pengarang buku Stewardship dan Empowered Manager) mendefinisikan kemampuan melayani (stewardship) dengan pengertian "memegang sesuatu dengan kepercayaan orang lain". Dalam suatu organisasi, setiap level manajemen, dari top management sampai shoop floor semuanya mempunyai peranan penting dalam memegang organisasi mereka dengan kepercayaan kepada kebaikan masyarakat yang lebih besar. Kepemimpinan pelayan, seperti kemampuan melayani, yang pertama dan terutama adalah memiliki komitmen untuk melayani kebutuhan orang lain. Hal ini tentunya menekankan adanya keterbukaan dan kejujuran, bukan pengendalian atau pengawasan.

Kesembilan, memiliki komitmen pada pertumbuhan manusia. Pemimpin pelayan berkeyakinan bahwa manusia mempunyai nilai intrinsik yang melampaui sumbangan nyata yang telah mereka berikan selama ini. Dalam sifatnya yang seperti ini, pemimpin pelayan sangat berkomitmen terhadap pertumbuhan pribadi, profesional dan spiritual setiap individu di dalam organisasi. Dalam praktiknya hal ini bisa dikembangkan dengan cara melakukan pengembangan pribadi dan profesional, menaruh perhatian pribadi pada gagasan dan saran karyawan atau anggota, memberikan dorongan kepada keterlibatan pekerja dalam pengambilan keputusan, toleran terhadap kesalahan dan sebagainya.

Kesepuluh, membangun komunitas/masyarakat di tempat kerja (building community in the workplace). Membangun komunitas ini mencakup membangun komunitas yang baik antar karyawan, antarpimpinan dan bawahan, dan membangun komunitas masyarakat dan pelanggan. Pemimpin pelayan menyadari bahwa pergeseran komitmen lokal ke suatu lingkungan yang lebih besar merupakan pembentuk utama kehidupan manusia. Lingkungan kerja yang kondusif secara internal dan eksternal diharapkan akan meningkatkan performansi organisasi secara maksimal. Kemampuan pemimpin pelayan dalam menciptakan suasana rasa saling percaya akan membentuk kerja sama yang cerdas dalam suatu tim kerja. Dengan ketulusan dan keteladan yang dimiliki oleh pemimpin pelayan, rasa saling percaya dapat ditumbuhkan. 
Ciri khas kepemimpinan pelayan seperti yang telah disebutkan bukan suatu harga mati, melainkan masih banyak ciri lain yang dimiliki oleh seorang pemimpin pelayan. Salah satu yang penting adalah bahwa kepemimpinan pelayan itu dimulai dari diri sendiri. Artinya, seorang pemimpin dapat melaksanakan kepemimpinan pelayan jika ia memiliki semangat yang tulus dalam dirinya untuk menjadi yang terdepan dalam pelayanan. Dengan kata lain, keteladanan menjadi faktor kunci bagi keberhasilan model kepemimpinan pelayan.

\section{SIMPULAN}

Dari paparan dapat disimpulkan bahwa keterlibatan unsur iman ataupun spiritual dalam konsep kepemimpinan menjadi jelas dalam model kepemimpinan pelayan. Sudah saatnya pula model kepemimpinan pelayan ini diterapkan lebih intens di negeri ini. Implikasinya, semoga pemilu 2014 juga dapat menghasilkan keterpilihan kader pemimpin yang potensial dalam menerapkan model kepemimpinan pelayan di Indonesia. Bukankah masyarakat Indonesia yang dikenal religius ini juga diharapkan dapat kembali pada kereligiusannya, sehingga dalam melaksanakan tingkah laku kehidupan sehari-harinya dapat lebih beretika dan bermoral, jauh dari anarkisme, rasisme, maupun perlakuan diskriminatif lainnya, serta terbebas dari politik balik modal. Oleh karena itu, realisasi

kepemimpinan yang dilandasi ketulusan dan kesungguhan diperlukan. Pelaksanaan model kepemimpinan pelayan dengan dilandasi prinsip keimanan diharapkan mampu mengembalikan kondisi bangsa Indonesia dari keterpurukan selama ini.

\section{DAFTAR PUSTAKA}

Arifin, A. R. (1968). Leadership Theory, Pengembangan dan Filosofi Kepemimpinan. Jakarta: Dinas Latihan Djabatan Lembaga Administrasi Negara.

Berndt, H. (2006). Agama yang Bertindak - Kesaksian Hidup dari Berbagai Tradisi. a.b. A. Widyamartaya. Yogyakarta: Kanisius.

DePree, M. (2003). Leadership is an Art. Random House, LLC.

Freeman, G. T. (2011). Spirituality and servant leadership: a conceptual model and research proposal. Emerging Leadership Journeys, 4(1), 120-140.

Greenleaf, R. K. dan Frick, D. M. (2008). A Life of Servant Leadership. San Francisco, California: Berret Kochler.

Greenleaf, R. K., Don M. Frick, dan Spears, L. C. (1996). On Becoming a Servant Leader. California: Wiley.

Sahertian, P. (2012). The spiritual leadership dimension in relation to other value-based leadership in organization. International Journal of Humanities and Social Science, 2(15), 284-290.

Senge, P. M. (1994). The Fifth Discipline. New York: Double Day Act Publishing Group, Inc.

Susanto, A. B. dan Masri, S.P.R. (2010). 60 Management Gems: Applying Management Wisdom in Life. Jakarta: Gramedia Pustaka Utama.

Tugiman, H. (1999). Budaya Jawa dan Mundurnya Presiden Soeharto. Yogyakarta: Kanisius. 